\title{
Membership Characteristics and Financial Performance of Investment Groups Investing in Securities Market in Kenya
}

\author{
Samuel O. Onyuma \\ School of Business \& Economics, Laikipia University, Kenya
}

\begin{abstract}
Investment groups provide a system of mobilizing together capital, lowering risks per individual and availing cheap capital for microenterprise growth. How the membership structure dimensions of an investment group affect its financial makeup is not well understood. The objective of the study was to assess the role of membership characteristics in the financial performance of investment groups in Kenya. Descriptive survey design was used and stratified sampling technique applied to select group members and investment groups. The data collected was analyzed using inferential statistics via regression analysis. The results indicate that group membership structure dimensions, such as experience, gender, occupation, business training and ethnic diversity, has a positive and statistically significant effect on financial performance of investment groups, which participate in securities markets in Kenya. Policies that entrench gender issues in investment groups and encourage creation of investment groups which are ethically balanced and occupationally diverse are critical in the success of such groups. Policies should be crafted by the investments group lobby outfits, which will facilitate training programs and forums to educate the members on investment skills and proper management practices as well as need for diversification of group investment portfolios.
\end{abstract}

Keywords: Group Membership Characteristics; Group Financial Performance; Group Ethnic Diversity; Kenya Association of Investment Groups; Chama Investments.

DOI: $10.7176 / \mathrm{JESD} / 11-10-15$

Publication date:May $31^{\text {st }} 2020$

\section{Introduction}

This paper takes a look at the phenomenal growth of, and membership in, investment groups, particularly in Kenya. The investigation runs an eye over investment groups in the context of the ownership society, the financial performance of such organizations and what it has meant to be involved in particular groups since the bubble of the Kenyan securities market. During the 2003-2018, Kenyan capital markets underwent a dramatic transformation in which Kenyans heavily invested in stocks, once the province of a privileged elite, with this form of securities investment becoming a mass activity involving millions of Kenyans. This came with the rise of investment groups, through which many people across the socio-economic spectrum became investors for the first time. These new investors pour billions of shillings annually into the Kenyan securities market and hold significant positions in some of Kenyan largest listed companies. In addition, different types of entrepreneurial ventures have popped-up in Kenya, thanks to the emergence of investment groups.

In the last decade, there has been a growing attention on investments viewed as a tool for economic development across the world. Investments means the commitment of funds, which have been saved from current consumption, to purchase financial instruments or other assets with the hope that some benefits will accrue in future in form of interest, dividend income, or appreciation of the value of the instrument. Typical working people worldwide are joining forces to form investment groups, which are voluntary associations of a few people who pool money to save in order to do joint investments. Such groups do have a manageable size to facilitate constructive discussions regarding investments and enough members to generate sufficient funds through regular contributions for the main purpose of investing.

\subsection{Evolution of Investment Groups in Kenya}

An investment group is a group of individuals who come together with an aim of pooling financial resources and investing jointly. Group members regularly meet and together make investment decisions through a voting process and prepare minutes, or gather information and make investment transactions outside the group. Popularly known as Chama in Kenya, they mimic informal cooperative society that is normally used to pool and invest savings by many individuals in Africa, and particularly Kenya. Even the Capital Markets Authority has recognized the potential of investment groups by noting that informal investment groups, have been investing in multi-billionshilling projects in various sectors of the economy, by pooling together financial resources.

Originally, investment groups were really informal women's groups. However, over the years they have grown in sophistication and currently even men significantly participate in such groups. It is, therefore, a phenomenon that currently cuts across gender, social status and even age (Kibue, 2013). Initially, Investment groups were organized as rotating savings and credits association (ROSCA), whereby members of a group would each contribute a fixed amount of money during each meeting and then the total amount would be given to one 
member. The Investment group has since evolved to be more than just a rotating savings and credit association (KAIG, 2016), into an investment vehicle.

The investment groups either have, therefore, been transformed into saving and investment groups from selfhelp groups or were formed for that purpose right from inception. Generally, these groups are not a get-rich-quick schemes, as members do focus on the long-term investments. Since they are financial partnerships, some investment groups may incorporate to protect members' assets and to facilitate compliance with the accounting rules observed by law. An investment group represents an archetypal example of an organization in which interactional processes can be observed. Such groups can be composed of people of different business experiences, gender, ethnic, occupational and business training backgrounds.

Based on a European model going back several generations, the first investment group was founded in Texas in 1898 and has existed in the United States for at least a century, though they did not become extremely popular until the 1990s when they constituted the major vehicle of the popular finance that has attracted so much attention from the media and policy makers. During the 1990s, the popularization of investment groups in the United States was facilitated by several organizational and technical developments most notably being that of discount brokerage firms and the Internet, which lowered transaction costs and made it possible to invest efficiently as a group.

The informal savings groups are self-help groups divided into three categories, which are financial, welfare and investment groups. The first category, which is generally, the most common groups, is financial Self-help groups - the ROSCAs or Accumulating Savings and Credit Associations (ASCAs). These informal associations come together for savings - ASCRAs - and lend out funds with certain percentage of interest - ROSCAs - in a regular basis. The second category is welfare groups or support groups, in which members provide each other with various types of assistance, usually nonprofessional and nonmaterial, for a particular common problem.

The third category is investment groups, which are vehicles for investments usually in land, the securities market, or businesses ventures. The purpose of forming investment groups, according to Kirui \& Onyuma (2019), is to buy assets, exchange business ideas, network and mobilize funds for investments. Nationally, there are 1800 investment groups in Kenya registered by the Kenya Association of Investment Groups (KAIG) and holding over Ksh.469 bn, equivalent to US $\$ 4,690 \mathrm{mn}(\mathrm{KAIG}, 2016)$. Some of the successful investment groups in Kenya are Transcentury Ltd, Centum Investment Ltd (Wainana, 2012), as well as Home Africa Ltd, the three having even transformed into successful listed companies with regional presence in Africa.

Investment groups with members who are experienced in the field of business and economics have a high chance of success. The greater understanding of the ways in which people learn to work in entrepreneurial ways is needed if significant advance in entrepreneurial activity is to take place since learning is critical to entrepreneurial effectiveness (Rae \& Carswell, 2000). Learning is an experiential process through which concepts are derived from and modified by experience. The experience of the entrepreneur is one factor that explains the difference in external financing levels available to small businesses. Group members however, are usually amateur investors who connect with other investors to learn about investing techniques and to get advice and tips on investments, especially in the area of financial securities.

Informal self-help groups have now become investment groups whereby members' intention is to pool together resources with the aim of creating wealth. They are no longer restricted to close family, friends and workmates but are open to different individuals who are seen to bring different expertise that add value to the group. Investment groups have grown in sophistication, complexity and diversity which necessitate proper planning and management. Investment groups are now investing in various sectors including, transport, agriculture, real estates, and even financial securities traded in securities markets.

Investment groups are currently not regulated under any specific Regulation. The KAIG is an umbrella body for investment groups in Kenya, where most of these groups can voluntarily register to become members Financial institutions in the money markets as well as capital markets have realized the financial value and capital mobilization potential of investment groups and are providing financial products that target them as consumers. For instance, most financial institutions have special finance packages specifically for investment groups. These packages are tailored to suit the groups, for example through offering high interest rates on savings, offering loans at reduced rates and also ensuring that no charges are incurred on the savings account. Software developers are also coming up with accounting and financial software packages that enable investment groups to digitally manage their financial records and also provide easy accessibility to members (Mbogo, 2016).

Men and women have different approaches to investing and the combination of this in a decision making group can produce a synergistic diversity of views that is well suited to a dynamic external environment. Men are more overconfident than women, as the latter are more risk averse. Younger and unmarried women are usually risk takers while older and married ones avoid taking risk. One of Harrington's most intriguing findings is that groups of men and women together are more profitable than single-sex groups (Harringon, 2008).

Investment groups generate capital from the monthly contributions from the members. Members can agree to have a target figure to kick start the investments where they are all required to put in a certain amount. Sources of financing therefore can include equity, which can be raised either internally or externally. Equity has a minimum 
cash outflow unlike debts in which interests are paid periodically (Ou \& Haynes, 2006). Other sources of funds available to investment groups include debts. Short-term debt advantages include zero interest rate in some shortterm debt cases such as in the case of trade credit and lower costs of flotation than those of long-term loans or equity. Interests are also allowable expenses in tax computations (Jun \& Jen, 2003). Another source of finance is from government initiatives like Women and Youth Enterprise Funds, like is the case in Kenya.

Investment groups play a critical role in Kenya's capital formation, which is a key ingredient in the realization of Vision 2030. Investment groups are therefore the unsung heroes of the investment world. They are expected to contribute greatly in mobilizing local capital and to command more ownership in the local economy, leading to economic development, independence from donors and closing the income generation gap. Investment decisionmaking process is considered critical for every investor and it is a cognitive process which results in the selection of a course of action from several alternatives. Investors need to make wise decisions on whom to join up with to form an investment group and whether or not to formalize their group. Investment groups can conduct economic activity in many forms and must decide whether to organize a close or publicly held corporation, a general or limited partnership, or just a self-help group. The assessment of group financial performance in this context becomes highly essential. The objective of the study was to determine the role of group membership structure on financial performance of investment groups operating in Kenya.

\section{Reviewed Literature}

This study was premised on the Modern Portfolio Theory, developed by Markowitz (1952), which hypothesized that the greater the investment risk the higher the returns. It is also based on the concept that risk-averse investors can construct efficient portfolios in order to optimize or maximize expected return based on a given levels of market risk. This theory is relevant for this study because Kenyan investment groups do engage in different sector investments as a way of diversifying their investment portfolio and also due to the fact that investment in some economic sectors like real estates are more profitable in the long run than others.

Empirical literature analyzing issues relating to investment groups are generally scanty globally. Available evidence is even thinner in African countries, including Kenya. Assessing the investment groups and their performance, Gakigi \& Njeru (2015) looked at the challenges faced by investment groups on performance but failed to study the how group membership structure determines its financial performance. Ichara (2014) also determined the factors influencing wealth creation in investment groups in Kenya. Focusing the effect of strategic planning, management and execution of investments on wealth creation among investment groups in Kenya, the study found that strategic planning affects wealth creation among the investment groups in Kenya. In addition, Ogutu (2014) conducted a study on influence of investment groups on creation of SMEs in Nairobi, employing descriptive survey design and founded that investment groups highly influences the formation of small and medium enterprises through resource mobilization, sharing of business ideas, spreading risks and taking advantage of social networks of the group members.

Furthermore, Muturi (2012) evaluated the determinants of participation in rotating savings and credit associations in urban informal settlements of Mathare Slum in Nairobi using a multi-dimensional model. Results indicate that participation in ROSCAs is for varied motives the main ones being saving, insurance, keeping away money from spouses and socialization. Hezron (2015) conducted a study on the effect of corporate governance on financial performance of investment managers in Kenya using a descriptive survey research design through descriptive and simple regression approaches. The study found that corporate governance influences the financial performance of investment managers. The study was unidimensional and assumed a direct relationship between corporate governance and financial performance of investment Managers.

It seems that having a group of interested dedicated people is not a guarantee that an investment group will have a very good financial performance. An investment group needs a variety of men and women who will bring in diverse and unique differentiated individual skills and experiences to the group. Some of the skills and experiences have been acquired as a result investing in different industries over some time, being in different occupations over time or having undergone some business training. Overconfident investors, in the context of securities markets tend to overestimate their abilities or the precision of their knowledge. Consequently, they usually hold riskier investment portfolios and trade more than maximizing expected utility would suggest (Barber \& Odean, 2001). The investment experience and age have a significant impact on the degree of overconfidence that goes surprisingly in opposite direction (Menkhoff, Schmeling \& Schmidt, 2013). Most interest in risky financial investments is expressed by participants with no investment experience, given the opportunity to choose among a mix of investments including risk-based fund option. The participants that are willing to take higher risks to give themselves the chance of making higher returns tend to be young Collard, \& Breuer, (2009). Men are risk takers who trade securities more than women do. A study indicates that men were more overconfident than women were; men traded more and perform worse than women (Barber \& Odean, 2001)

Business training is an important factor influencing entrepreneurial performance and income because it increases education level in general. Training affects both female and male entrepreneurship in a positive manner, 
although what is more is the fact that the influence of business training is greater on female entrepreneurial activity than on male entrepreneurship (Shirokova \& Tsyganova, 2010). The personal as well as environmental factors influence investors in formulating their perceptions on investment avenues (Mohanta \& Debasish, 2011). In decisions relating to investment, investors have certain weaknesses like cognitive and emotional that take a predominating role. Investors adopt some investment avenues after analyzing different factors that are influenced by their internal and external environments. Men and women have very different occupational experiences and therefore gender differences in investing may be seen as a result (Kirui \& Onyuma, 2019). The gender gap in investing experience is because of women less likely to have been offered opportunities, according to U.S. Department of Labor Women's Bureau (1994). Investors hardly act rationally in taking decisions while investing. Investors simply react on the available information possessed by them and react accordingly. Investors should as far as possible try to make fundamental, technical and financial analysis before investing in the shares. There are many considerations while investing such as tax planning, future needs, safety of investments and recurring income. Investors who possess financial information therefore make better investments decisions (Singh \& Yadav, 2016).

Studying the investment clubs in America, Harrington (2010) most intriguing findings was that gender-based differences in investing can create a diversity premium - in which groups of men and women together are more profitable than single-sex groups. In examining the sources of this effect, Harrington delves into the interpersonal dynamics that distinguish effective decision-making groups from their dysfunctional counterparts. Harrington (2010) also examined decision-making processes in investment groups, employing the conceptual and analytical tools of economic sociology. As formal associations for consultation and discussion of financial decisions, Harrington found that investment groups provide an interesting arena for scholarly observation in which decisionmaking processes in finance are made transparent. She analyzed how the composition of investment groups, on the one hand, and the way in which information is used in-group processes, on the other hand, impact on investment performance. Harrington's findings on the diversity premium suggest interesting implications. Group heterogeneity impacts on investment performance in positive ways, the more decision-making processes in the group can withstand the numerous forces pushing members toward conformity of opinion (Harrington, 2010).

Using the principles of behavioral finance, the psychological concept of individual attachment style, influence mainly the tilt of urban investors to different available investment avenues and their investment preference process. There is significant role of income and occupation in investment avenue selection by the investors (Mohanta et al, 2011). Education is one of the factors that affect positively on growth of firms (King \& McGrath, 2002). Investors with business knowledge have the ability to get appropriate information from the business environment that is relevant and useful for their investments (Chittithaworn, Islam, Keawchana, \& Yusuf, 2011). Business training therefore helps investors to cope with the latest accounting systems, information technology, management concepts and production (Jones, 2004). Business training lead to some changes in business practices for women already in business, but had no impact on business profits, sales or capital stock. However, both profitability and business practices of the new entrants were increased by training, suggesting that business training may be more effective for new investment than for existing businesses (De Mel, McKenzie, \& Woodruff, 2014). Due to gender differences in education or business networks, women might be relatively uninformed about investment opportunities and they might be untrained in basic cost-benefit analysis (Karlan, 2003).

Those investment groups with larger proportion of members with business education and (or) vocational training, have been found to be better placed to adapt their enterprises to constantly changing business environments (King et al., 2002). A research carried out through a field experiment in Tanzania, which jointly investigated the importance of a human capital intervention (business training) and a financial capital intervention (business grant). Using data from three survey rounds, a lab experiment and administrative records of the microfinance institution, they concluded that business training is essential to transform financial capital into productive investments (Berge, Bjorvatn, Juniwaty \& Tungodden, 2012).

Business training of investors always lead to improved profitability of an investment. Entrepreneurship training lead to improved business knowledge, practices and revenue (Karlan \& Valdivia, 2011). Individuals can be taught to engage in certain good business practices, which can lead to increased sales. Business training enabled the entrepreneurs to better identify business opportunities, leading to changes in business practices and ultimately higher sales and profits (Bjorvatn, \&Tungodden, 2010). Development of new financial products and the complexity of financial markets have led to an increased importance of improving financial literacy amongst investors. A significant relationship between financial literacy and investment decisions and women have a lower level of financial literacy than men (Hassan \& Anood, 2009).

A study by the National Center on Women and Aging (1998) concluded that men have more informational diversity than women do. Women, unlike men did not read specialty financial publications such as Wall Street Journal on investors and business, but got their business ideas from friends, relatives and general interest newspapers. Men get investing ideas form financial specialty publications and internet (Harrington, 2010). The most important principal factors that influence investment decisions are past performance of the company stock, expected stock split, bonus, dividend policy and expected corporate earnings. Investors are enlightened on the 
factors that are necessary to maximize their wealth in the capital market (Obamuyi, 2013). In addition, Harrington shows that most Americans approach investing not only to make a profit but also to make a statement. In effect, portfolios have become like consumer products, serving both utilitarian and social ends. This ties into the growth of socially responsible investing and shareholder activism - matters relevant not only to social scientists but also to corporate leaders, policymakers, and the millions of Kenyans who are planning for retirement.

The economic liberalization and globalization have brought a fervent environment for the common and small investors who are willing to participate in the various investment avenues available. Investments are done in various investment avenues with the expectation of capital appreciation and short and long term earnings. The investor should therefore analyze the market cautiously and then make investment decision (Velmurugan, Selvam, \& Nazar, 2015). Conflict of preference, ethnicity, and prejudice can easily lead to management difficulties in an investment group; however, an ethnic mix can also bring about a variety in abilities, experiences, cultures which may be productive and may lead to innovation and creativity (Alesina \& Ferrara, 2005). Ethnic diversity is likely to have important cultural, economic, fiscal, and developmental benefits. In the short run however, ethnic diversity tend to reduce social solidarity and social capital. New evidence from the US suggests that in ethnically diverse neighborhoods residents of all races tend to 'hunker down'. Trust (even of one's own race) is lower, altruism and community cooperation is rarer (Putnam, 2007).

In many developing countries, the ethnic makeup of local business communities is quite different from that of the population at large. It is not common for members of a particular ethnic group to account for an overwhelming proportion of entrepreneurs (Fafchamps, 2003). Sociologists have emphasized that African entrepreneurs prefer to do business with members of their own ethnic group (Himbara, 1994). They have emphasized the role that trust and reputation among individuals and communities play in creating an enabling environment for trade. There is a consensus that sharing the same ethnicity and religion are elements that favor the establishment of trust (Cornell \& Welch, 1996). Members who share the same ethnicity as the chairperson are 20 to 25 percentage points more likely to borrow from the group or from other members; hence, ethnicity matters in gaining access to group resources, especially in the form of cheap loans (La Ferrara, 2002).

Members of more homogeneous groups, both in terms of geographical proximity and of cultural affiliation, are more likely to save and to repay their loans. "Cultural" homogeneity is measured through a score attributed by enumerators to each respondent based on his/her language, dress and hairstyle. These findings suggest that monitoring and enforcement within groups are easier, the greater the social affinity among their members (Berge et al., 2012). The basic idea of network effects is that information about opportunities circulates along interpersonal networks. Investors with better networks collect more accurate information that enables them reach market opportunities more aggressively. Network implications of ethnicity account for the differences in firm productivity, investment and growth prospects (Bigsten, Kimuyu \& Lundvall, 2000). Network effects have a strong and systematic effect on trust and information sharing (Fafchamps, 2003).

Informality is pervasive amongst firms in developing countries, and simple comparisons of formal and informal firms usually reveal that formal firms are more productive and profitable. Formal firms are defined as those that are registered to pay taxes (have a tax code), a common indicator of formality in the literature (Fajnzylber, Maloney\& Montes-Rojas, 2009; McKenzie \& Sakho, 2010; Rand \& Torm, 2012). The attributes of group formalization are organizational form, financial management, accounting and auditing, financial reporting and tax returns.

The choice of organizational form for business has been of interest to investors. The law offers a menu of choices, including liability companies and general partnerships. Each organizational form has its own set of default rules. Prevailing theories based on unlimited liability, profit sharing, and illiquidity are insufficient and, the choice of form decision is quite complex. It depends on a variety of factors, including the behavior of other similarly situated firms that the decision makers consider competitors for prestige and clients. Nonetheless, it is apparent that unlimited liability is generally considered burdensome, and it is the authors' prediction that, at some point in time, nearly all the firms in their sample will choose to file as limited liability partnerships (Baker \& Krawiec, 2005).

Businesses planning in general involve minimization of income taxes, limitation of individual liability, and provision of flexibility and ease in operation (Esch \& Spaccarotella, 1994). By taxing the income of corporate firms at a different rate than non-corporate firms, taxes can play an important role in a firm's choice of organizational form. The sensitivity of the organizational form decision to tax rates provides a key indicator of the distortion created by the corporate income tax. A significant impact of the relative taxation of corporate to personal income on the share of real economic activity that is done by corporations. The double taxation issue bears quite heavily on the choice of organizational form (Goolsbee, 2004).

Financial management is one of the key aspects of the well-being and survival of a business. There is a clear evidence that three important core financial management components were used by the MSEs namely financial planning and control, financial accounting, and working capital management. Other financial management components namely, financial analysis, management accounting, and capital budgeting were used by a smaller 
percentage of these enterprises (Hoe, 2010).

Large corporations have reaped the benefits of following best practice in financial and management accounting to become more competitive. Such best practice can be used as a benchmark to improve performance in micro and small enterprises but very few studies have been undertaken to determine this. Like large firms, MSEs also require adequate and sophisticated management accounting techniques and systems to manage better scarce resources hence better financial performance (Nandan, 2010).

A business borrowing from a bank to finance the working capital will be subject to increased financial requirements that come with a cost from the bank's interest charges. Cash flow problems of many small businesses are made worse by poor financial management and in particular lack of planning cash requirements. Overtrading in the MSE business would result to working capital constraints and affect business profitability which arises from increased working capital requirements (Jarvis, Kitching, Curran \& Lightfoot, 1996). MSEs have limited access to long term capital markets and rely heavily on owner financing, trade credit and short term bank loans to finance their needed investment in cash, accounts receivables and inventory (Chittenden, Poutziouris \& Michaelas, 1998). Managing cash flows and cash conversion cycle is a critical component of overall financial management for firms especially those who are capital constrained and more reliant on short term sources of finance (Deakins, Logan \& Steele, 2001). The issue of finance has been identified as an immediate reason why businesses in developing countries fail to start or to progress (Abor, 2007). An investment group can have various sources of funds, after it has been in business for a while, including debt from financial institutions.

Audits are performed to ascertain the validity and reliability of financial information provided by the managers of the reporting entity and an assessment of the entity Internal Control System. Effective and proper accounting system has a profound impact in successful auditing of Small and Medium Enterprises and by extension on the performances of the firms (Onyuma, 2020; Olasupo, Sorunke \& Olawuyi, 2016). A positive relationship between the voluntary purchase of business advice and MSE performance and that performance is further enhanced when business advice is purchased jointly with auditing (Carey, 2015).

\section{Methodology}

The study collected information from investment group members' opinions regarding how group membership structure may interact with the financial performance of investment groups. The study employed a descriptive survey research design because such design provides an in depth investigation of the case. The study targeted a population of 17,945 registered groups in Nakuru County, as per a database maintained by Nakuru County Government in Kenya. A sample of 130 group members and 130 investment groups, which invest in securities traded at the Nairobi Securities Exchange, were selected. The study collected primary data using a pre-tested questionnaire consisting of a series of questions and other prompts for gathering information. The piloting of the instrument was done with two investment groups in a different sub-county within the County. The primary data was analyzed using a descriptive analysis as well as inferential statistics via regression analysis using SPSS version 25.

\subsection{Empirical Analysis}

The data analysis was conducted to establish the role of group membership structure in financial performance using the following empirical model:

$\mathrm{Y}_{\mathrm{i}}=\beta_{0}+\beta_{1}$ OCUP $_{\mathrm{i}}+\beta_{2}$ GEND $_{\mathrm{i}}++\beta_{3} \mathrm{EXPR}_{\mathrm{i}}+\beta_{4} \mathrm{ETDV}_{\mathrm{i}}+\beta_{5} \mathrm{BTRN}_{\mathrm{i}}+\theta_{\mathrm{i}}$

Where:

$\mathrm{Y}_{i}$ - Group financial performance captured as return on investment and measured as net profit after taxes divided by total amount of invested capital, expressed as a percentage.

$O C U P_{i}$ - Occupation of the $i$ th group member, a categorical variable taking into account the various types of occupation for group members.

$G E N D_{i}-$ Gender is a categorical variable of the $i$ th group member, coded as $1=$ male, zero otherwise.

$E X P R_{i}-$ Member experience of the $i$ th group members measured as the number of years in undertaking investments. $E T D V_{i}-$ Group ethnic diversity of the $i$ th investment group, a categorical variable coded as $1=$ group is ethnically diverse, zero otherwise.

$B T R N_{i}$ - Business training for the $i$ th group member measured coded as 1 = group member has undergone some business training, zero otherwise.

$\beta_{0}-\beta_{5}$ are the parameters to be estimated.

$\theta_{i}$ - The disturbance term, financial performance that cannot be explained by the estimated model.

\section{Results and Discussion}

The descriptive results, not presented here, indicate that about 66.3 percent of the investment group members had invested for a period of less than 4 years, while 33.7 percent had invested for a period more than five years. Male respondent constituted about 48 percent while females were 52 percent. The gender of the respondents was 
therefore not balanced, which further confirms the fact that there is gender imbalance of the investment groups in the study area. The results further show that majority of investment group members were entrepreneurs (49 percent) followed by teacher (17.3 percent) and accountants at 13.3 percent. This implies that investment groups with members from different occupations can easily invest in different industries. About 51 percent of group members had obtained business training while the rest had not gone through such training. Also, 71.8 percent of investment group members belonged to groups that were ethnically diverse, with the rest were in ethnically homogenous groups. Investment groups had also spread their investments across the four investment portfolios of enterprise, real estate (44.5 percent), financial securities such as listed shares and government and corporate bonds (42.8 percent), with the highest investment being in the real estate and lowest in both government and corporate bonds. The growth in securities market activities has attracted many investment groups to financial securities investments. Variable means for each of the group membership factors such as experience of members, gender, occupation, business training and ethnic diversity were computed and regressed against financial performance mean. This was necessary in order to determine how variability in financial performance was explained by changes in dimensions of group membership structure.

Based on the data analysis, the results indicate an $\mathrm{Adj} . \mathrm{R}^{2}$ value of 0.85 , implying that 85 percent of the total variation in group financial performance was explained by changes in dimensions of group membership structure. The analysis of variance was used to determine whether the regression model was a good fit for the survey data. The results obtained show that the model was significant with an $F(5,97)=116.586$, at $\mathrm{p}<0.05$. This means that the model was statistically significance in predicting the influence of the independent variables on the dependent variable.

Table 1: Effect of Group Member Structure on Financial Performance

\begin{tabular}{|c|c|c|c|c|c|}
\hline & \multicolumn{2}{|c|}{ Unstandardized Coefficients } & \multirow{2}{*}{$\begin{array}{l}\text { Standardized Coefficients } \\
\text { Beta }\end{array}$} & \multirow[t]{2}{*}{$\mathrm{t}$} & \multirow[t]{2}{*}{ Sig. } \\
\hline & $\mathrm{B}$ & Std. Error & & & \\
\hline (Constant) & 7.120 & 3.254 & & -2.188 & .031 \\
\hline OCUP & .302 & .063 & .204 & 4.827 & .000 \\
\hline XEPR & -.144 & .053 & -.111 & -2.700 & .008 \\
\hline GNDR & -.099 & .045 & -.093 & -2.207 & .030 \\
\hline BTRN & .532 & .023 & .901 & 23.071 & .000 \\
\hline ETDV & -.178 & .050 & -.143 & -3.574 & .001 \\
\hline
\end{tabular}

a. Dependent Variable: Return on Investments

Table 1 shows the beta coefficients for each variable and their level of significances. The results shows the coefficient of -0.144 for experience. This indicates that the coefficient is greater than zero and statistically significant at the 5 percent level, implying that a unit reduction in group experience causes an increase of 0.144 in financial performance. Experienced investors portray a behavioral pattern in their investments profile that depicts risk aversion. As investors age, their experience level increases hence they shy away from risky ventures. This result supports those of Nandan (2010) that cognitive aging affects investment skills negatively as much knowledge is depicted by portfolio decision, as well as Barber, et al.(2001) that young investors are willing to take higher levels of risk that is associated with higher returns than older investors are. This is also associated with the high degree of overconfidence.

Group homogeneity in terms of gender significantly and statistically affect group financial returns. ( $\beta=-0.99$; $\mathrm{p}=0.03$ ), at the 5 per cent level of significance. This implies that a unit reduction in gender homogeneity causes an increase of 0.99 in financial performance. As a group tends towards being a mixed gender group, its financial performance improves. Homogenous groups are outperformed by mixed gender groups. The finding of this study is in line with those of Langowitz \& Minniti (2007) and Verheul, Stel \& Thurik (2006), who found that women are more conservative in their choice of investment avenues and are unwilling to take risks. On the other hand, groups of men alone take more risks and could get into great loss. Moreover, women tend to possess less business experience. Their business growth is slower, suggesting a preference for lower risk and lower confidence.

From the results, the coefficient for group occupational mix was $0.302(p=0.00)$ which was statistically significant at the 5 per cent level of significance. This implies that a unit increase in occupational mix causes an increase of 0.302 in group financial performance. When more investors from diverse occupational backgrounds join an investment group, the financial performance of this group will improve. This is so because knowledge gained from being in a certain occupation influence investors' behavioral biases in investment decision making. Such group members react on the available information possessed by them and act accordingly. This findings support those of (Levišauskaitė \& Kartašova, 2013).

In addition, the findings also indicate that the coefficient for business training was $0.532(p=0.00)$ which was statistically significant and the 5 per cent level of significance. This implies that a unit increase in business training leads to 0.532 unit increase in financial performance. Business training helps investors to cope with the latest accounting systems, information technology, management concepts and production techniques. The training acquired in any educational field and the experience gained are important factors affecting the behavior and 
investment decisions of investors. This finding supports those by (Berge et al. (2012), \& Bjorvatn et al. (2010), that business education enables the entrepreneurs to better identify business opportunities, to get appropriate information hence leading to changes in business practices and ultimately higher sales and profits.

Lastly, the results indicates a coefficient for ethnic mix to be -0.178 ( $p=0.001)$, a finding which was statistically significant at the 5 per cent level of significance. This implies that a unit decrease in ethnic mix leads to 0.143 unit increase in financial performance. Ethnically homogenous investment groups perform better financially because monitoring and enforcing of rules and regulations within investment groups are easier due to greater social affinity among the members than would be with heterogeneously ethnic groups. This finding supports that of Fafchamps (2003) that network effects are also greater in ethnically homogeneous groups since investors with better networks collect more accurate information, which enables them to seek out market opportunities more aggressively. Network effects have a strong and systematic effect on trust and information sharing and the results of this study is in agreement with this conclusion.

\section{Conclusion and Policy Prescription}

The findings revealed that group membership structure dimensions such as member experience, gender, occupation, business training and ethnic diversity have significant positive effect on group financial performance. Regression results further indicate a significant positive effect. Group heterogeneity affects investment performance in positive ways because a well-diversified group has members that can bring about a variety in abilities, investment experiences, knowledge and cultures that may be productive and may lead to innovation and creativity. Given the findings, the study recommends that the government should come up with policies that encourage gender mainstreaming in investment groups and registration of investment groups with members from differs occupational backgrounds. Policies should be crafted by the investments groups associations and lobby outfits which will facilitate training programs and forums to educate the members on business skills and proper management practices in their groups. Diversification of group investments vehicles as well as membership should be encouraged since it is vital in furthering the financial performance of investment groups in developing economies, especially in African countries.

\section{References}

Abor, J. (2007). Debt policy and performance of SMEs: Evidence from Ghanaian and South African firms. The Journal of Risk Finance, 8(4), 364-379.

Alesina, A., \& Ferrara, E. L. (2005). Ethnic diversity and economic performance. Journal of economic literature, 43(3), 762-800.

Baker, S., \& Krawiec, K. D. (2005). The economics of limited liability: An Empirical study of New York Law Firms. University of Illinois Law Review (1): 107-169.

Berge, L. I. O., Bjorvatn, K., Juniwaty, K. S., \& Tungodden, B. (2012). Business training in Tanzania: From research-driven experiment to local implementation. Journal of African Economies, 21(5), 808-827.

Bigsten, A., Kimuyu, P., \& Lundvall, K. (2000). Informality, ethnicity and productivity: evidence from small manufacturers in Kenya. Department of Economics, Göteborg University.

Bjorvatn, K., \&Tungodden, B. (2010). Teaching business in Tanzania: Evaluating participation and performance. Journal of the European Economic Association, 8(2-3), 561-570

Carey, P. J. (2015). External accountants' business advice and SME performance. Pacific Accounting Review, 27(2), 166-188.

Chittenden, F., Poutziouris, P., \& Michaelas, N. (1998). Financial management and working capital practices in UK SMEs. Manchester: Manchester Business School.

Chittithaworn, C., Islam, M. A., Keawchana, T., \& Yusuf, D. H. M. (2011). Factors affecting business success of small \& medium enterprises (SMEs) in Thailand. Asian Social Science, 7(5), 180.

Collard, S. \& Breuer, Z. (2009) 'Attitudes towards investment choice and risk within the personal accounts scheme: Report of a qualitative study'. No. 565 Retrieved on $7^{\text {th }}$ November 2017 from http //www.bristol.ac.uk/geography/research/pfrc/themes /psa/pfrc0902.pdf

Cornell, B., \& Welch, I. (1996). Culture, information, and screening discrimination. Journal of political Economy, 104(3), 542-571.

De Mel, S., McKenzie, D., \& Woodruff, C. (2014). Business training and female enterprise start-up, growth, and dynamics: Experimental evidence from Sri Lanka. Journal of Development Economics, 106, 199-210.

Deakins, D., Logan, D., \& Steele, L. (2001). The financial management of the small enterprise. London: Certified Accountants Educational Trust.

Esch, K. D., \& Spaccarotella, P. L. (1994). Limited Liability Companies as an Alternative Choice of Entity for Farming and Ranching Operations in the State of Nebraska. Creighton Law Review, 28, 19.

Fafchamps, M., (2003). Ethnicity and networks in African trade. Contributions to Economic Analysis \& Policy, 2 (1), Article 14, Berkeley Electronic Press. 
Fajnzylber, P., Maloney, W. F., \& Montes-Rojas, G. V. (2009). Releasing constraints to growth or pushing on a string? Policies and performance of Mexican micro-firms. The Journal of Development Studies, 45:10271047.

Goolsbee, A. (2004). The impact of the corporate income tax: evidence from state organizational form data. Journal of Public Economics, 88(11), 2283-2299.

Harington, B. (2010). Popup Finance: Investment Clubs \& the New Investor Populism. Princeton University Press.

Al-Tamimi, H. \& Kalli, A. B. (2009). Financial literacy and investment decisions of UAE investors. The Journal of Risk Finance, 10(5), 500-516.

Himbara, D. (1994). The failed Africanization of commerce and industry in Kenya. World Development, 22(3), 469-482.

Hoe, C. H. (2010). Financial management practices: an in-depth study among the CEOs of Small and Medium Enterprises (SMEs). International Review of Business Research Papers, 6(6), 13-35.

Jarvis, R., Kitching, J., Curran, J. \& Lightfoot, G. A. (1996). The Financial Management of Small Firms: An Alternative Perspective. ACCA Report No.490. London: Certified Accountants Educational Trust.

Jones, J. (2004). Training and development, and business growth: A study of Australian manufacturing smallmedium sized enterprises. Asia Pacific journal of human resources, 42(1), 96-121.

Jun, S. G., \& Jen, F. C. (2003). Trade-off model of debt maturity structure. Review of Quantitative Finance and Accounting, 20(1), 5-34.

KAIG (Kenya Association of Investment Groups) (2016) KAIG Chama Handbook. Nairobi: KAIG.

Karlan, D., \& Valdivia, M. (2011). Teaching entrepreneurship: Impact of business training on microfinance clients and institutions. Review of Economics and statistics, 93(2), 510-527.

Karlan, D., (2003). Social Capital and Group Banking. Princeton University Research Program in Development Studies Working Paper.

Kibue, S. M. (2013). Management of Strategic Change at Family Bank Limited, Kenya. Unpublished MBA Project, University of Nairobi.

King, K. \& McGrath S. (2002) Globalisation, Enterprise and Knowledge: Educational Training and Development, International Review of Education, 50(1), 74-76.

Kirui, R. \& Onyuma, S. O. (2019) Effect of Group Composition and Formalization on Financial Performance of Investment Groups in Kenya. International Journal of Economics, Finance and Management Sciences, 7, (2): 65-73.

La Ferrara, E. (2002). Self-help groups and income generation in the informal settlements of Nairobi. Journal of African Economies, 11(1), 61-89.

Langowitz, N., \& Minniti, M. (2007). The entrepreneurial propensity of women. Entrepreneurship theory and practice, 31(3), 341-364.

Levišauskaitè, K., \& Kartašova, J. (2013). The impact of individual investor's occupation and investment experience on their decisions to invest. Business Systems \& Economics, 2(2): 120-129.

Markowitz, H. (1952). Portfolio Selection. Journal of Finance, 7(1): 77-91.

Mbogo, P. W. (2016) Effect of real estate investment strategies on financial performance of investment groups in Kenya. (Unpublished MSc Project, University of Nairobi).

McKenzie, D., \& Sakho, Y. S. (2010). Does it pay firms to register for taxes? The impact of formality on firm profitability. Journal of Development Economics, 91(1), 15-24.

Menkhoff, L., Schmeling, M., \& Schmidt, U. (2013). Overconfidence, experience, and professionalism: An experimental study. Journal of Economic Behavior \& Organization, 86, 92-101.

Mohanta, G., \& Debasish, S. S. (2011). A study on investment preferences among urban investors in Orissa. Prerna Journal of Management thought \& practice, 3(1), 1-9.

Mugenda, A. G. (2008). Social Science Research: Theory and Principles. Nairobi ARTS Press.

Nandan, R. (2010). Management accounting needs of SMEs and the role of professional accountants: A renewed research agenda. Journal of applied management accounting research, 8(1), 65-78.

National Center on Women \& Aging. (1998). Financial challenges for mature women. Waltham, MA: Brandeis University. Retrieved $12^{\text {th }}$ March 2020, http://www.heller.brandeis.edu/national/exsum.htm.

Obamuyi, T. M. (2013). Factors influencing investment decisions in capital market: A study of individual investors in Nigeria. Organizations and markets in emerging economies, 4(7), 141-161.

Olasupo, S. F., Sorunke, O. A., \& Olawuyi, L. (2016). Statutory Auditing and Performance of Small and Medium Scale Enterprises in Lagos State, South West Nigeria. International Journal of Academic Research in Business and Social Sciences, 6(9), 58-67.

Onyuma, S.O (2020) Organizational Structure and Financial Performance of Investment Groups Participating in the Kenyan Capital Markets. Journal of Poverty, Investment \& Development, 54 (forthcoming).

Ou, C., \& Haynes, G. W. (2006). Acquisition of additional equity capital by small firms-findings from the national survey of small business finances. Small Business Economics, 27(2-3), 157-168. 
Putnam, R. D. (2007). E pluribus unum: Diversity and community in the twenty first century the 2006 Johan Skytte Prize Lecture. Scandinavian political studies, 30(2), 137-174.

Rae, D., \& Carswell, M. (2000). Using a life-story approach in researching entrepreneurial learning: the development of a conceptual model and its implications in the design of learning experiences. Education and training, 42(5) 220-228.

Rand, J., \& Torm, N. (2012). The benefits of formalization: Evidence from Vietnamese manufacturing MSEs. World development, 40(5), 983-998.

Shirokova, G., \& Tsyganova, T. (2010). Gender differences in entrepreneurship: evidence from gem data. Organizations and markets in emerging economies, (1 (1), 120-141.

U.S. Department of Labor, Women's Bureau (1994). Handbook on women workers: Trends and issues. Washington, DC: U.S. Government Printing Office.

Velmurugan, G., Selvam, V., \& Nazar, N. A. (2015). An empirical analysis on perception of Investors' Towards Various Investment Avenues. Mediterranean Journal of Social Sciences, 6(4), 427-435.

Verheul, I., Stel, A. V., \& Thurik, R. (2006). Explaining female and male entrepreneurship at the country level. Entrepreneurship and regional development, 18(2), 151-183.

Wainaina, T. (2012). Chama to Conglomerate. Reinvesting Your Investment Group. New Delhi, India. 